\title{
IDENTITY STUDIES
}

\author{
(C) M.B. Bashkirov
}

GABYSHEV: IDENTITY AT THE INTERSECTION OF TWO CULTURES

Keywords: Gabyshev, Siberia, Yakutia, shamanism, neoshamanism, shaman warrior, holy foolishness, per- sonal identity, penal psychiatry

\begin{abstract}
The figure of "shaman warrior" Aleksandr Gabyshev from Yakutsk became the object of attention in social media in 2019-2020. The interest toward Gabyshev was sparked both by the goal he declared ("to drive President Vladimir Putin out of the Kremlin") and by his peculiar personality. This article is drawn on a wide range of materials gathered in the course of research work on a visual documentary about Gabyshev. The worldview of the "shaman warrior" was a paradoxical tangle of the native Yakut culture and the Russian Orthodox culture. In many ways Gabyshev adhered to the line of behavior typical of "holy fools" in the Russian Orthodox tradition. Indeed, his behavior and personality image could be seen as grounded in a sequence of contradictions that seemed meaningless and illogical in the context of the shamanic tradition. Yet aspects both of neoshamanism and of "blessed foolishness" were important assets that let him creatively develop his personal identity.
\end{abstract}

This article is a translation of: М.Б. Башкиров. “Шаман-воин” Александр Габышев: идентичность на стыке двух культур // Etnograficheskoe Obozrenie. 2021. No 5. P. 130146. DOI: $10.31857 / \mathrm{S} 086954150017419-0$

In the summer of 2019, the Russian media space was filled with numerous reports about Aleksandr Gabyshev, who called himself a "shaman warrior" and walked from Yakutsk to Moscow. The "shaman warrior" had a mission he used to talk about: "to exorcise the demon out of the Kremlin in 2021", who was the President of Russia Vladimir Putin. In a very short time, "Sasha the Shaman" from an extravagant eccentric who walks the roads of Siberia began to turn into a media figure and even a kind of a spiritual leader for his followers and some part of the audience who followed him on social networks.

In the media space, the story of the "shaman warrior" has come to its peak twice. Both times this was due to the state's repressive actions against Gabyshev. Thus, for the first time, he was arrested at the end of September 2019 on the border of Buryatia and the Irkutsk Region and taken to Yakutsk, where a criminal case was opened against him under Article

Mikhail Bashkirov | https://orcid.org/0000-0002-5605-6543 | bashkiroffm@gmail.com | Institute for Humanitarian Research and North Indigenous Peoples Problems of the Siberian Branch of the RAS (1 Petrovskogo St., Yakutsk, 677027, Russia)

Etnograficheskoe Obozrenie. 2021. № 6. P. 253-268. https://doi.org/10.31857/S086954150017608-8 (C) Russian Academy of Science | (C) Institute of Ethnology and Anthropology, RAS ISSN 0869-5415 | http://journal.iea.ras.ru 


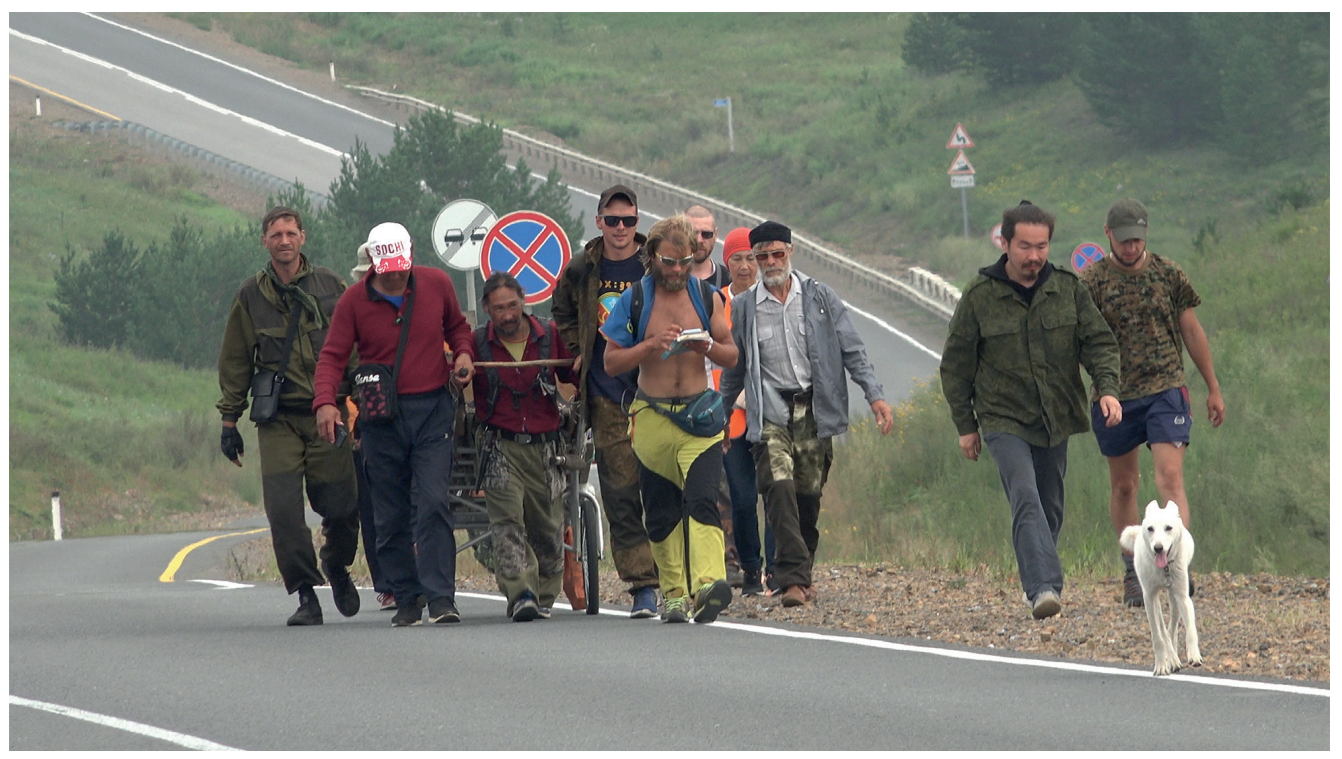

Fig. 1. A. Gabyshev with followers. Trans-Baikal Territory (photo by B. Bashkirova, August 2019)

280 of the Criminal Code of the Russian Federation ("Public calls to carry out extremist activities"). At that time, the fame of the "shaman warrior" went beyond the all-Russian level and reached the world level: such media as The New Times, BBC, Guardian, etc. wrote about him. A number of Russian politicians and even the press secretary of the President of the Russian Federation Dmitry Peskov talked about Gabyshev (Peskov Does Not Know 2019). The second time the media wrote about the "shaman warrior" especially actively was at the end of May 2020, after Gabyshev's house was taken by storm by the police, and the "shaman warrior" was forcibly taken to the Yakut Republican Neuropsychiatric Dispensary, where he was until 22 July 2020.

Gabyshev's way (both literally and figuratively) is counter to ideas about the norms and customary behavior of representatives of (neo)shamanism in the Republic of Sakha (Yakutia) and in Russia (see, for example: Ilyakhov 1994). On the other hand, in terms of the polyvariety of behavior strategies of modern Russian (neo)shamans and transformations in modern Russian (neo)shamanism, the "shaman warrior" fits well into the existing diversity and rather motley religious-spiritual mosaic (see: Kharitonova 2020). Undoubtedly, Gabyshev falls out of the traditional shamanic roles. He neither treats nor reads fortune: he is a "shaman warrior", in other words, a shaman exorcist fighting demons. Thus, when meeting the author of the article, after mentioning the book Shamanism by Ksenofontov, Gabyshev immediately categorically stated that he was far from traditional shamanism: "I only know my destiny, my way. I know the history of shamanism superficially and I don't want to go deep into it" (PMA 2019-2020: Gabyshev). Gabyshev's case demonstrates not so much a violation of existing canons (within the framework of the Yakut shamanic tradition) as an attempt to invent his own rituals and even his own distinctive shamanic identity. All this created fertile ground for accusations of imposture on Gabyshev ("a fake shaman"). The combination of a political action and magical-mystical ritual (the rite of exile) into a single whole became the basis for all kinds of political conjectures and speculations. For example, the head of Yakutia in one of the interviews hinted that the US State Department could stand behind Gabyshev (How One Yakut 2019). 
The image of Gabyshev, replicated in many media and social networks, caused violent disputes. The use of mass media optics and the polarity of assessments of the audience of social networks have led to the formation of numerous stereotypes: "urban madman", "psycho", "hype man", "honest Siberian man", "new Rasputin", etc. Obviously, such clichés cannot explain Gabyshev's motivation and behavior, often devoid of the usual everyday logic. To some extent, this article is an attempt (probably not an exhaustive one) to answer the question: who is Aleksandr Gabyshev?

\section{Methodological notes}

The idea of this article arose in the process of working on a documentary film about Gabyshev (authors B. Bashkirova and M. Bashkirov, Ethnofond Film Company LLC and Les Steppes Production). The source base of this article includes the set of audiovisual materials collected during the work on the film from July 2019 to February 2020. Filming was carried out exclusively by the film authors; more than 150 hours of video materials have been filmed to date. The film character was observed from "the closest possible distance"; during the filming, the authors were incorporated into the life world of Gabyshev and his followers. This technique does not imply any preparation of the character for filming and is aimed at fixing what is happening "here and now".

Thus, all the "interviews" recorded during this time began only at the behest of the "shaman warrior" and are monologues uttered off the cuff, without any special preparation. The dialogues that arose between the authors and the film character during the filming process were also almost always off the cuff and used to be everyday, even routine ones. This filming technique excludes any situations artificially modeled by the authors, especially manipulations. Despite the fact that the film character got used to the constant presence of the camera in his daily life, he obviously never forgot about it. For ethical reasons, the filming was not carried out in secret, except for a few times. However, after each time Gabyshev was informed about it. In those situations when he asked not to film him, the filming was not carried out. The authors filmed not only Gabyshev but also members of his "squad", as well as people who knew him before the "campaign".

These materials can be conditionally divided into two large groups. The first group includes videos filmed in July-August 2019, when Gabyshev, along with a group of supporters who joined him, walked along the Trans-Baikal Territory and the Republic of Buryatia. The second group of video recordings was made in Yakutsk between the end of September 2019 and February 2020. At that time, Gabyshev was under investigation and was almost constantly at home surrounded by sympathizers and supporters. In addition, there is a significant set of sources represented in the media: reports and interviews by Gabyshev. Also, the "shaman warrior" found his voice through social networks. Almost on a daily basis from November 2019 to January 2020, he delivered video messages and went live on YouTube channels of his supporters (the channels "Crow and Shaman", "Lekha Cat", etc.). Some of the materials used in the article were presented at the round table "The Mission of the Shaman in Modern Society: Traditions and New Sacred Technologies" at the Institute for Humanities Research and Indigenous Studies of the North of the Siberian Branch of the Russian Academy of Sciences (Yakutsk) in November 2019.

In terms of the ethical dimension of this story and the situation in which "Sasha the Shaman" appeared, it should be noted that this article does not set the task of "whitewashing" Gabyshev. Nevertheless, it must be admitted that for a long time (during the investigation period), he was in a difficult psychological situation. In Gabyshev's case, it is also possible to discuss the threat of the revival of punitive psychiatry, a seemingly forgotten Soviet practice of combating dissent (Akhmirova 2020). The author of the article does not go into assessing his mental state, much less making any diagnosis. One can only testify that for the entire time of his communication with Gabyshev in the filming process, the latter did not 
call for violent actions or for anything even remotely reminiscent of "extremism". On the contrary, he stubbornly, if not fanatically, emphasized the non-violent nature of his campaign and "casting out the demon". In short, his philosophy is reduced to a maxim, which he repeated with unfailing regularity: "Taking revenge is a sin, forgive!"

\title{
Milestones in Gabyshev's biography and stages of the "shaman warrior's" way
}

Aleksandr Prokopyevich Gabyshev was born in the Olekminsky District of the Republic of Sakha (Yakutia) on 22 November 1968. He served in the Soviet army, studied at the Yakut State University at the Faculty of History. In the 1990s, he changed several jobs (he was a welder, janitor, etc.). The turning point in his life was the death of his wife in the early $2000 \mathrm{~s}$ due to illness (Gabyshev does not like to remember this period). After that, experiencing the loss of a loved one, for about three years he lived in the taiga, where he built a small dugout in the forest near the village of Vladimirovka (a suburb of Yakutsk), and virtually did not maintain contact with the outside world:

\begin{abstract}
When you are a shaman, both body and mind are open, and everything comes to mind. Now I am already well, but ideas are saturated, that's it. If you live in the wilderness for a couple of years, you will understand. Alone. I went grocery shopping, I wasn't entirely alone - my mother visited me, but lived separately from people. I lived for two years in the Tabaginsky cape, a year in Ulakhan-An, also in the forest. I spent the winter there for two years, I had a yurt there. The locals helped, they all knew that there was a shaman. Legend (AFD 20192020: Gabyshev).
\end{abstract}

When Aleksandr Gabyshev returned to civilization, he was not ever the same. According to the recollections of Vladimir Popov, who was observing Gabyshev at the end of the 2000s, a colleague from the Institute for Humanities Research and Indigenous Studies of the North, Aleksandr could be met in the streets of Yakutsk in extravagant clothes embroidered with symbols of all world religions. Then he called himself "a Christian monk-warrior - a warrior of light", played a home-made musical instrument, sang traditional Yakut chants Toyuki on Orthodox themes, and gave the lessons of self-invented hand-to-hand combat "Thunderfist" for food (Ibid: Popov). Presumably, already in this period, the contours of identity and a new image began to form, consisting of two natures - a shaman and a warrior. It can be noted that neither Gabyshev himself nor any of the persons who knew him before the campaign mentioned that he mastered the techniques of immersion in an altered state of consciousness, faced a "shamanic disease", underwent any initiation, or had supersensitive extrasensory abilities. He further interpreted the suffering from the loss of a loved one and the subsequent changes in his mental state as a sign of his own chosenness. Moreover, the status of a "shaman" was needed as both cultural and psychological protection from society:

... several times they almost shoved me into a psychiatric hospital... My mother protected me, she understood: he is making a rite of initiation, do not disturb him. She said to me: go to the forest, son, no one will disturb you there, live there. I went to the forest, God did not give me any healing abilities, I can't do anything, neither heal with my fingers, nor read fortune, I know how to fight, as they say. And then I ask God: what is all this for? I am a Christian, the Christ says: love your neighbor, turn your right cheek, this is a contradiction, how is it, you teach me to do harm. "Wait for your time to come", - a voice from above answers me. This is crazy, I was crazy for three years, it's good that my mother sent me there, otherwise I would still be in a psychiatric hospital. This is how he pointed to Putin, here is your enemy, a beast, not a man, drive him out and that's it, but by that time I had left the forest. Another person is already being born there... (Shaman 2019)

In March 2019, a resident of Yakutsk, Aleksandr Gabyshev, set off with a homemade cart, onto which he loaded the things necessary for the trip (a stove, a tent, etc.). A year earlier, Gabyshev had made an unsuccessful attempt to launch a "campaign against 
Moscow". Near the city of Aldan, his dog was hit by a car, he tried to nurse the animal, but the dog died. The dog's death eventually became the reason for its return to Yakutsk, as he perceived it as a "bad sign". Throughout the spring, he walked alone on foot southward along the A-360 highway. In the Trans-Baikal Territory, on the P-297 highway, the first associates joined him - Angel (Aleksandr) and Raven (Evgeniy). Every day he walked 15 to $30 \mathrm{~km}$. On the way, people constantly approached him: locals, truckers, random motorists. Gradually, through social networks, more and more people learned about Gabyshev's trip. In Chita, for the first (and last) time, he spoke at a meeting of the local opposition, where he highlighted simple points of his "political" program, which will be touched upon below. Gabyshev further refused to speak publicly.

In the Transbaikal area, new supporters began to join him, and soon their number reached ten people (Gabyshev calls them his "heavenly squad"). From that moment on, the author of the article observed first-hand the campaign of the "shaman warrior" for three weeks. On the border with Buryatia, the number of Gabyshev's supporters (or, rather, companions) reached two dozen people; it was already approaching 30 people in the area of Lake Baikal. The "squad" reached Ulan-Ude when the mayoral elections were being held; those days there was unrest in the capital of Buryatia. The main reasons for this were suspicions of fraud in the mayoral elections and injustice towards "Sasha the Shaman" (one of his companions was detained by the police for 15 days). The political situation in the city predetermined the attitude of the local authorities towards Gabyshev and the movement he headed. "Well, you know, there is an accompanying thief, $<\ldots>$ The Shaman does business, when credit cards are thrown in and money is simply collected from people. This action - I don't know if it is political or commercial...", - said the head of Buryatia on the air of the capital's radio station (Golubev 2019). For his part, the author of the article can testify as follows: although the "squad" operated on donations from sympathizers, Gabyshev did not manage the money and tried to distance himself from financial issues. The same applies to the political component: the current political agenda was of little interest to him: "I don't know who of the authorities was pecked by the fried chicken there, it is covered with mysticism. And the Buryats ... an apolitical calm people, once stirred up the rallies. This is more mysticism, we did not really participate in those events. They began to hold rallies. My position is just to go along the road" (AFD 2019-2020: Gabyshev). On September 19, the "shaman warrior" was arrested near the village of Babushkin and convoyed to Yakutsk - to the place from where his journey began. Already in Yakutsk, Gabyshev urged his supporters not to continue the journey, but, on the contrary, to go home. Soon, the members of the "squad" went home (Squad 2019).

In Yakutsk, the "shaman warrior" appeared in completely different circumstances. Having travel restrictions imposed on himself, he faced increased attention from the media and the Yakut public. Almost immediately, a group of people, or a "support group", sympathizing with Gabyshev, was formed; they helped him financially and morally. Already on the first day after the transfer, a psychiatric examination of Gabyshev was carried out at a local psychoneurologic dispensary. His lawyers challenged the legality of this procedure. Soon, Gabyshev recorded a video message in which he urged the "squad" to go to Yakutsk, as well as conducted several public "rituals" designed to "clear" the road to Moscow. In response to appeals, about a dozen members of the "squad" came to him. The most striking event that the "squad" managed to organize was a rally in support of the "shaman warrior": more than three hundred people gathered in a twenty-degree frost. By mid-November, most of the "squad" (with the exception of a few people) had gone home.

On 8 December 2019, Gabyshev, together with two supporters, again attempted to go to Moscow, but two days later he was again detained by police officers for a far-fetched reason. During the detention, which looked more like a special operation involving dozens of police officers, the "ritual" sword held by Gabyshev was confiscated from the "shaman warrior" (Kozhedubov 2019). Gabyshev spent the night at the police station. Moreover, from a legal point of view, the situation looked doubtful: Gabyshev was never charged, his travel 


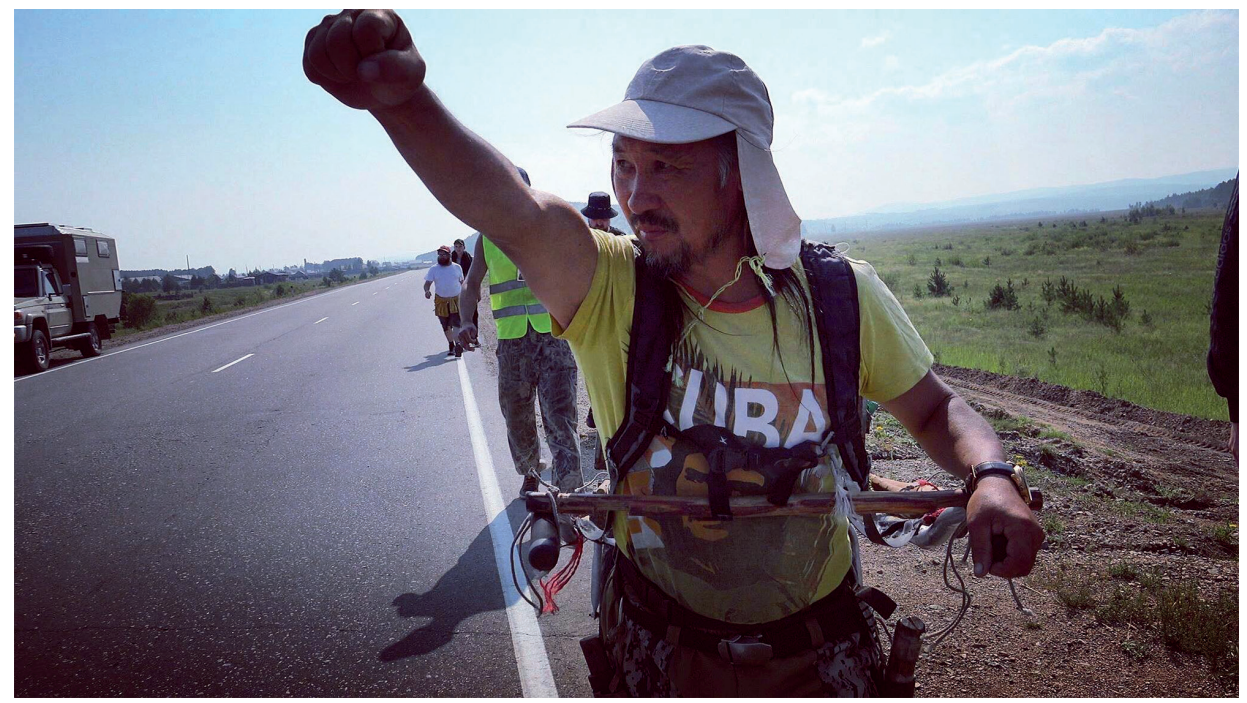

Fig. 2. A. Gabyshev. Trans-Baikal Territory (photo by B. Bashkirova, August 2019)

restrictions had expired in October, and he was detained in the urban district of Yakutsk. "I spent four days in the taiga and performed a mystical rite, as I am a shaman. For this purpose, I needed to go to the taiga with my people. Due to my religious convictions, I need time alone to perform the rite of exorcism. Will every shaman be watched? Will they come with riot police? What is it coming to? They even take away cult items!" (AFD 2019-2020: Gabyshev).

After it became clear that the Yakut security forces would not allow him to leave the city, Gabyshev focused on public speaking on the Internet. He even had an analog of his "show" on YouTube, which he called "Lightning Insights". Despite his arrest in December, already on January 12, he publicly announced that in March he would again continue his campaign into Moscow from the place (the area of the settlement of Babushkin), where he was arrested in September (Shaman 2020). At the end of January, Gabyshev's supporters, who had stayed with him since the fall and lived at his home, faced repression. Under various pretexts, they were detained by the police and expelled from Yakutia. In response to these actions, Gabyshev disappeared for several days. As it turned out later, he made a desperate escape attempt. However, according to his statement, he was detained again, this time somewhere in the Trans-Baikal Territory (AFD 2019-2020: Gabyshev). In the spring, Gabyshev minimized his public activity for some time, but in May 2020, he again announced that a new campaign into Moscow would begin at the end of June, during the celebration of the Yakut holiday Ysyakh. Apparently, these statements provoked a new detention of Gabyshev and, as a result, he ended up in the Yakutsk Republican Psychoneurological Dispensary. This situation has caused quite fair fears that the tools of penal psychiatry may be applied to him. Unexpectedly, on 22 July 2020, Gabyshev was discharged from the hospital, after which he stated that he did not intend to continue his campaign and wanted to get on with his private life: "I am not going to call a squad on a campaign. Let it be only with permission from the authorities and only as my personal trip around the world. Everything must be official and with permission from the authorities" (cited from: Aleksandrova 2020). Less than a year later, on 27 January 2021, the situation in May was completely repeated. Gabyshev was again forcibly taken to the same neuropsychiatric dispensary a few days after he announced a new "campaign". This time he was betting that on the journey he would move 
on a white horse. In February 2021, the Investigative Committee of the Russian Federation opened a criminal case against him under Article 318 "The use of violence against a representative of the authorities". On 26 July 2021, the Yakutsk City Court found him guilty and sentenced him to compulsory treatment for an indefinite period. It seems that in this case one can put a fine point on it. Or is it an ellipsis?

\section{Paradoxes of Gabyshev's life-world}

Gabyshev constantly emphasized his dual nature (a shaman and a warrior), which turned over time into a kind of a "constant" of his personality. The identity of a "shaman warrior" created by Gabyshev did not arouse objections from his companions and a large audience of social networks. There are no similar examples in the Yakut culture, to which he periodically appeals (or, at least, they are not widely known). It can be assumed that the creation of the image of a "shaman warrior" was inspired by Castaneda's novels, which were popular in Russia in the 1990s (see, for example: Castaneda 1992). Gabyshev's duality often caused doubts about his shamanic status. A rather curious situation occurred on the road near Ulan-Ude, when the "shaman warrior", along with his companions, met a group of Buryat shamans from the Local Religious Organization of Shamans "Tengeri" (Shamans 2019). The main reproach Gabyshev heard was that he was not a real shaman, and a shamanic religion was incompatible with militant rhetoric. In other words, one cannot be simultaneously a shaman and a warrior. However, Gabyshev pointed to his own ethnicity: "Spirits choose their mediator on their own. This is not like the Buryats - they do some kind of a ritual to become a shaman. Everyone gets together, they have some kind of rules. It is not so with the northern peoples. The spirits will choose you, so they will choose at least one of you" (AFD 2019-2020: Gabyshev). Or he made vague references to the Yakut tradition: "...and when one of the guests, his fellow countryman from Yakutsk, asked: "Do they exist?" he answered: "They did", but did not explain anything else" (Egorov 2020).

Each of the natures of Gabyshev's personal identity had its own material-subject components. Thus, in summer and autumn, the "shaman warrior" carried a "ritual knife" and in winter Gabyshev began to appear with a "ritual sword" (batas), which he never parted with. Moreover, Gabyshev emphasized in every possible way the magical and mystical significance of the sword. In December, when Gabyshev was detained by the police, the sword was seized. Ironically, the loss of the sword did not upset him much, and the following is even more ironical: when the Investigative Committee of the Russian Federation returned the sword, Gabyshev lost interest in it and gave it to his supporter. The "shaman" also had attributes: a tambourine and a homemade one-stringed instrument, on which he performed traditional Yakut chants toyuki on Christian themes. In some cases, he sang the "Lord's Prayer" translated into Yakut, in other cases - motives of plots from the Old and New Testaments, for example, about the world creation (AFD 2019-2020: Gabyshev). The most striking episode with the participation of a tambourine, donated by someone on the road in the Republic of Buryatia, is associated with the same chants. It was a public shamanistic ritual, a recording of which was posted on YouTube on the same day (November 2019). The ritual was aimed at cleansing by the spirits the road to Moscow, where he was going to set off. In the spring of 2020, Gabyshev sent an audio recording of the prayer to the Blessed Virgin to the guitar accompaniment to his friends in WhatsApp.

Undoubtedly, Gabyshev's worldview is synthetic and combines elements of paganism and Orthodoxy. This kind of dual belief is not unique, but, on the contrary, is rather common in the (neo)shamanic environment (Kharitonova 2016: 110). "I am baptized... I believe in Christ and in shamans, too. Two faiths" (AFD 2019-2020: Gabyshev). In Gabyshev's case, the synthetic nature of religious views was also reflected externally - in the form of tattoos: letters are tattooed on Gabyshev's fingers (this is not a reference to the prison subculture, but his own work). On the right hand across the phalanges there is a word 


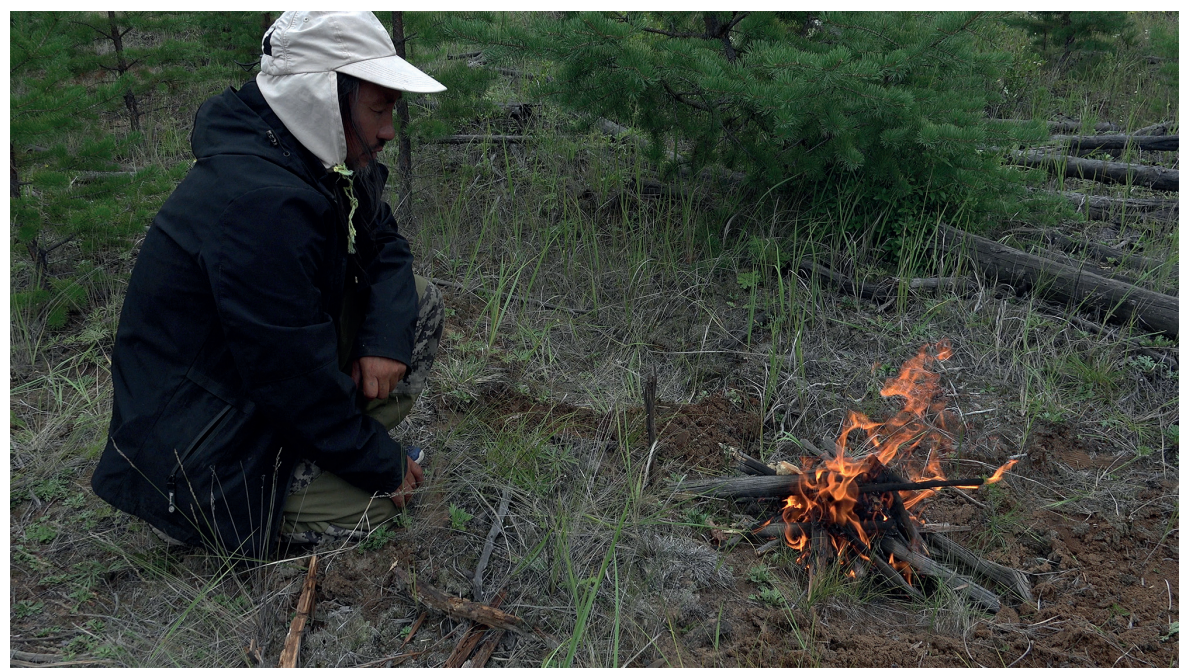

Fig. 3. A. Gabyshev performs the ritual of "feeding the fire" (photo by B. Bashkirova, August 2019)

"DOMM" is tattooed, on the left one - "AMEN" (on the little finger there are two Russian letters: " $H b$ "). From the Yakut language, the word "domm" can be roughly translated as "amen".

Another visual expression of synthetical character is the "shaman's coat of arms", with which he walked along the road and installed each time in the camp. "This is God of Light. This is my sign - God's lightning [he speaks Yakut illegibly. - Commented by the author]. My mother painted the coat of arms: "Dyosyokhoi Ai", the god of horse breeding. "Kyos khohun" - a northern nomad. The Savior" (Ibid.). There is a similar image of "God's lightning", also in the form of a tattoo, on Gabyshev's forehead and his left hand. The tattoos were made long before the campaign. After the arrest in Buryatia and the beginning of investigative actions, lightning signs appeared on Gabyshev's face - "Tanara signs", which, according to him, meant the anger of God (Ibid.). These signs were drawn with a felt-tip pen and refreshed from time to time.

This is God's lightning, now it is in anger. These are flashes of lightning in anger. Previously, there was only one sign. Just God's lightning. This is my name. Now God's lightning is in anger. A warning sign to the enemies. These are shamanic signs. The shaman is now angry that's all. It will wash off, when the good in the world triumphs, then it will wash off. The good is still in anger. Let the darkness tremble - the shaman has come (Interview 2019).

The image of the "shaman warrior" invented by Gabyshev exists within the framework of a certain plot, having a beginning and an end. The "middle" of the story is actually Gabyshev's way. Initially, he assumed that the way was a hike across the whole country. An interesting fact is cited in his documentary story "Dzhol" by V. Egorov, who accompanied Gabyshev on his journey for almost two months. In the Republic of Buryatia, near Lake Baikal, Gabyshev and his companions began to have concerns about the possibility of an early arrest. As a result, it was decided to rent a private bus and drive the rest of the way across the republic (several tens of kilometers) to the border with the Irkutsk Region. It was assumed that the Irkutsk authorities could react not so violently to the group's movement. The bus was already booked and arrived at the place, but at the last moment, Gabyshev behaved paradoxically and canceled the planned trip: "I forgot what I promised God in 
Yakutsk: to go on foot. If I go by bus, God will punish me and deprive me of my strength. I will go on foot" (quoted from: Egorov 2020).

Subsequently, after being detained and actually kept under house arrest (travel restrictions), Gabyshev interpreted his own way as "spiritual", and the hike did not have the same meaning as in the summer and autumn of 2019: "I'm waiting. I will be waiting for a long time, I have much time left before the mission is completed. If I reached Chita for three days, then if necessary, I will be in Moscow in a second, so guys, the heavenly game continues" (AFD 2019-2020: Gabyshev). These words were uttered by Gabyshev after his "informal" arrest in the Trans-Baikal Territory at the end of January 2020 and "transferring" to Yakutsk. The "escape" to Trans-Baikal was the result of the actions of the Yakut security officials directed against the supporters of the "shaman warrior" (all of them were forcibly expelled from Yakutia).

Gabyshev considers himself as a character of a story with its own dramatic laws and logic: "The character's destiny rises, then the fall necessarily occurs, captivity or something like that, the difficulties are so great, then he overcomes them, and the rise is even greater. This is the scenario. <...> That is why I already feel that this is God's scenario" (Ibid.). The worldview of the "shaman warrior" has an epic dimension. This peculiarity of his worldview is also emphasized by other persons: "The shaman's knowledge in the epic, for example, is simply amazing: he knows the entire Scandinavian epic, all the fairy tales. $\mathrm{He}$ is an amazingly well-read person" (Batalova 2019). Besides, Gabyshev has not mentioned the Yakut epic olonkho at all. Existing within the framework of the plot, the character encounters obstacles and transforms: "The caterpillar crawled along the road, slowly crawled, then appeared on the crossroads and turned into a cocoon. It was waiting for what would happen next. It knows that something that flies faster and higher, that is stronger and wiser than her, will emerge from the cocoon" (AFD 2019-2020: Gabyshev). Besides, again in a paradoxical way, Gabyshev periodically and deliberately deprived himself of the right to choose, giving the initiative to what he called "dark forces". He preserved the right to react to a certain situation:

If they choose the dark way, I will be imprisoned or appear in a psychiatric hospital... A warrior will awaken in me. There I have many strong warriors - they will all awaken and go the dark way. And we will definitely reach the Kremlin, already by the way of the warrior. I promise that, and neither prison walls nor hospital wards will hold me back. I am not as simple as it seems, I am a heavenly person, I am a heavenly warrior... If they choose the bright path, then... I will definitely go. Already in a bright way. I will walk like a shaman, like a white shaman. I have a two-word name: shaman and warrior. I will choose a shaman (Ibid.).

According to the laws of dramatic art, the existence of a character is impossible without striving to realize one's own goal. Gabyshev has emphasized many times that his mission to drive out the demon is of divine origin: "I have received a task - I must complete it" (Ibid.). When asked exactly how the expulsion should take place, Gabyshev often answered evasively. Only once there was a more or less precise instruction: "I know how to bind a demon" (quoted from: Egorov 2020). However, it has always been emphasized that these will be exclusively non-violent actions: "We just want to change this authoritarian leader, as I call him - the demon. To expel means to dismiss him, while abiding by the principles I have proclaimed. <..> Not a single hair will fall from his head" (AFD 2019-2020: Gabyshev). Moreover, the mission should be undertaken only in 2021, this was also declared by Gabyshev many times: "We will reach him in 2021. And he will be driven out - any of the campaigns, bright or dark ones, will end in expulsion, that's all" (Ibid.). Gabyshev never claimed that his shamanic specialization was the exorcism of demons, while he pointed out that Putin was not the only demon; he met them on the road, but did not engage in battle, but continued to walk towards the intended goal: "Dark demons, half-demons did not 
approach at all, they only watched. They were afraid of the light, their spirit is weaker than the spirit of light" (Ibid.).

Thus, Gabyshev's life-world largely fits into the paradigm of the plot of a dramatic work filled with many paradoxes. In this case, his own life becomes a projection of creativity and is equated with a work of art. By the way, individual creativity is not alien to professional shamanism (for more details see: Kharitonova 2004). Gabyshev's paradoxical, contradictory worldview and behavior at first glance can be simply explained by psychiatric diagnoses. However, upon closer examination, in Gabyshev's actions, one can see the model of behavior of an Orthodox holy fool. Being a person close to the Orthodox tradition ("a Christian monkwarrior - a warrior of light"), he could well come into contact with the hagiography of St. Basil the Blessed, Mikolka Svyat, or Procopius of Ustyug. In Gabyshev's behavior, it is easy to discern the properties inherent in Orthodox blessed foolishness: paradoxism, mysticism, the combination of the incompatible, play, destruction of the norm (Yurkov 2003: 52-69). Thus, he has repeatedly stressed that he considers himself a fool: "What to expect from a fool?" (AFD 2019-2020: Gabyshev). Mysticism can also be easily called the constant of his worldview. The identity of the "shaman warrior" is both an attempt to combine the incompatible and the destruction of the norm. This can also include an eccentric appearance: the missing teeth, a tattoo on the forehead, lightning drawn with a felt-tip pen - in short, "deliberate disgrace", according to Panchenko (Panchenko 1999).

Another feature of Gabyshev's worldview inherent in Orthodox holy foolishness is eschatological motives. "A holy fool constantly reminds of another true world, in spite of the existing world - untrue one; he is an active participant in the destruction of the latter, causing all kinds of evil, and a precursor, a prototype of the imminent Last Judgment over him" (Yurkov 2003: 60). The eschatological motive of the end of the "old world" and the onset of the "new world" was quite clearly manifested in Gabyshev's speech. He considered himself a harbinger of the onset of the new world, repeatedly repeating that where he passed, the new world had already begun:

The new world is following us - a whole tsunami of the new world. Those who don't understand will be sentenced by the court. They will die naturally and quickly. From some unknown diseases, from cataclysms. All people who don't understand will be erased by God. Why do they need people who take revenge and do not forgive... Everyone will be punished... It will be too late for them. <...> That's all God's punishment. And here is the new world (AFD 2019-2020: Gabyshev).

Within the framework of the tradition of Russian holy foolishness, one can clearer understand the meaning of the challenge he throws to the "tsar" represented by the President of the Russian Federation, calling him a "demon". That is why he has never described the "ritual of exile" precisely. "The king is necessary for the holy fool as a figure personifying the entire earthly structure, he is most responsible before God" (Yurkov 2003: 67). The author of the article does not presume to judge how consciously Gabyshev reproduces this model with his behavior, but, in his opinion, the parallels are quite eloquent. The same parallels can be quite accurately traced both in his relations with supporters and in his "political" program.

\section{Two wings and relationships in the group}

The first companions of the "shaman warrior" on the way to Moscow were Angel (Aleksandr, his surname is unknown) and Raven (Evgeniy Rostokin). Gabyshev gave new names to his companions, as he believed that each of them embodies the light and dark sides of his soul. They both adopted these names. Angel, who was making a round-the-world trip by hitchhiking at that moment, was the first to join Gabyshev in the Trans-Baikal Territory, the second one was Raven. Both Angel and Raven repeatedly defiantly performed the 
functions assigned to them by Gabyshev. This immediately caught the eye of outsiders. During the trip, Angel mainly talked about various spiritual practices, Gabyshev delegated his own powers to him from time to time, when during the stops visitors came to him looking for spiritual support or advice. In turn, Voron, a former prisoner who spent several years in correctional facilities, dealt only with problems related to the material component of the trip (providing food, equipment, firewood, etc.). "Next to Angel, a man of the new world, I feel like a child and behave like a child, make jokes, play around. Next to Raven I feel like a ruler right away" (AFD 2019-2020: Gabyshev).

After Chita, new sympathizers began to join Gabyshev, whom he began to call a "heavenly squad". He gave each of them a name: Bear Balu, Santa Claus, Cat, Wolf, Owl, Goblin, Valkyrie, Spirit, Warrior, etc. Nobody rejected the new names received from Gabyshev. At the same time, along with the new names, the old ones were also used (Sasha, Andrey, etc.). The names given by Gabyshev often had a figurative-artistic origin and, as a rule, corresponded to a certain inner essence of the newcomers or their traits of character: "if during the acquaintance or subsequent observation of the behavior and appearance of a newcomer the shaman made up an association with a character from fairy tales or fabulous stories, he gave him the name of this character and immediately informed everyone present, and from that moment on, the newcomer was treated like a character from a legend, saga or fairy tale" (Egorov 2020). Some group members even considered their names honorable and were proud of them: this relates to such names as, for example, Wolf or Spirit. It is curious that here Gabyshev considers himself not only as a character that exists in the plot of his own history but also as an author who creates the world around him. After being discharged from the Yakutsk Psychoneurological Dispensary, he eloquently emphasized this: "I involved people in my fantasies, my fairy tales. My past life was just my fairy tale" (quoted from: Aleksandrova 2020).

Closer to the border of Trans-Baikal and Buryatia, the number of people accompanying Gabyshev had already reached three dozen. They were strikingly different from each other in social and personal experience: among them were former prisoners, workers, retirees, students, adherents of "New Age", neoshamanism. There was no selection procedure for joining the "squad"; it was easy to join the group, as well as to leave. Initially, Gabyshev demanded that his companions observe simple rules: manifestations of any form of violence and the use of alcohol were prohibited. Later, the rules were supplemented by the need to comply with the orders given by Gabyshev. Orders had been non-violent and most often were associated with the performance of everyday domestic duties. In the "squad", conflicts often arose on domestic, ideological, and personal grounds. In most cases, the "shaman warrior" did not intervene in what was happening, distancing himself from such situations, but in exceptional moments he acted as a peacemaker. The "squad" existed on donations that sympathizers sent to Raven by bank transfers or gave on the road in the form of money or food.

Closer to the border with Buryatia, Gabyshev made an attempt to normalize the behavior of his companions and introduce elements of discipline: "You may be expelled for quarrels or fights. You are not expelled forever - it depends on the degree of guilt, for a week, for a month, neither corporal nor prison punishment, the only punishment is expulsion from the squad. Taking revenge is a sin. For malicious disobedience to my orders you will be expelled. We have discipline rules. As long as you are free settlers, your right to freedom is inviolable. You are free to come and go" (AFD 2019-2020: Gabyshev). The leadership of the "shaman warrior" has almost never been challenged by anyone. He was the only author of all the innovations in the squad's life: "The rules are in my head. We do not have democracy - it is still early for us. I teach them. When we solve this matter, we will have democracy, the rule of the people" (Ibid.). The audience of social networks often reproached Gabyshev for "dictatorship"; in turn, he repeatedly publicly responded to these attacks, speaking of the temporary need for a top-down order. "As soon as the goal is 


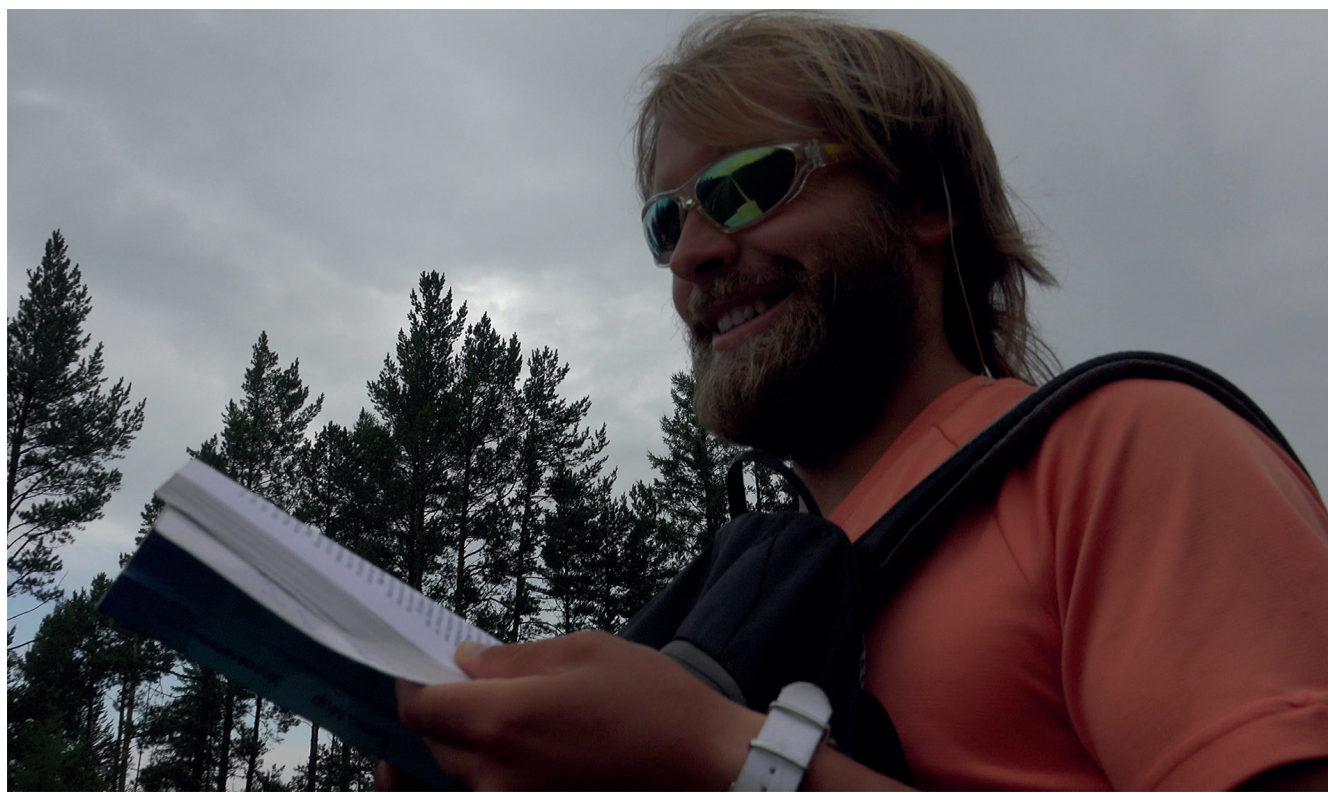

Fig. 4. Angel (Aleksandr) - "the shaman's bright wing”(photo by B. Bashkirova, August 2019)

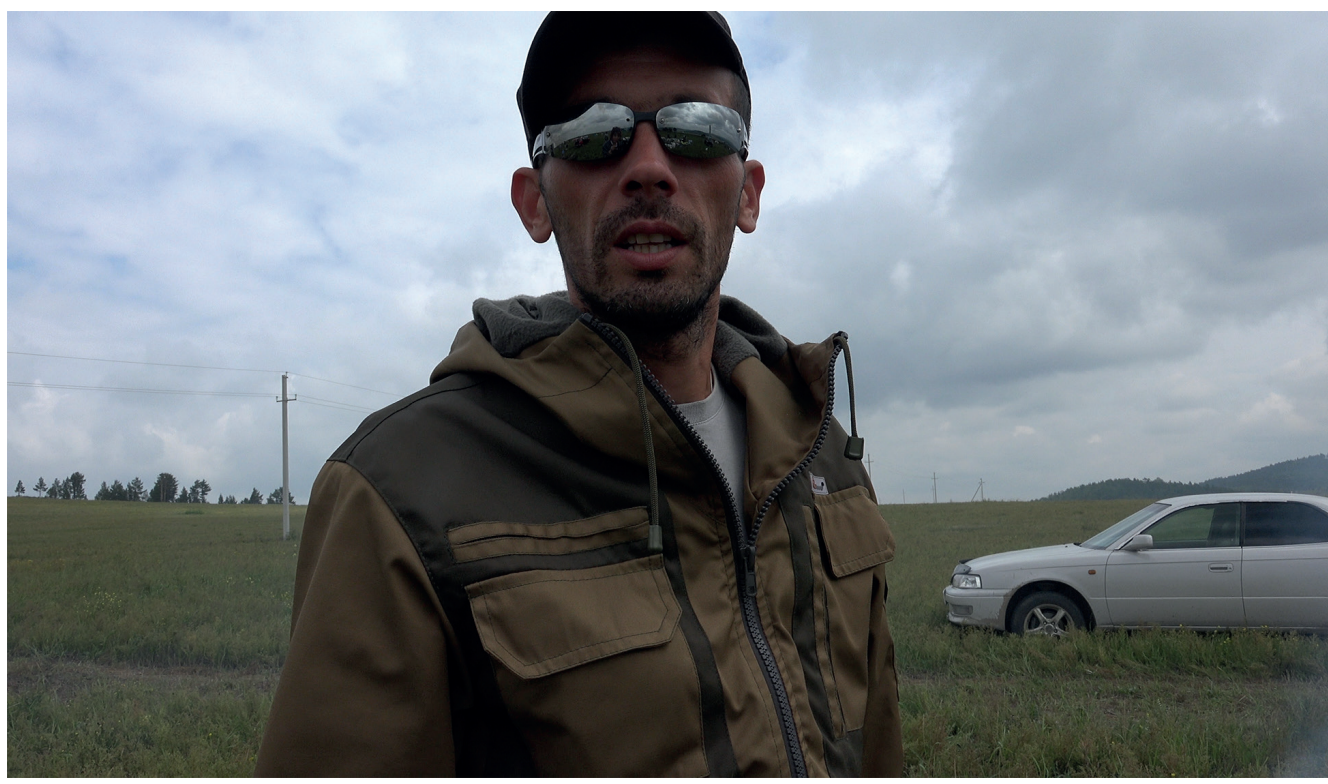

Fig. 5. Raven (Evgeniy Rostokin) - "the shaman's dark wing” (photo by B. Bashkirova, August 2019)

achieved, the squad will be disbanded. And I hope that never again for a thousand years it will not be formed by command" (Ibid.).

He also considered the "support group" that had formed around Gabyshev in Yakutsk as part of the "squad". It is noteworthy that for the most part, it consisted of women, while the squad members who were walking along the highway with Gabyshev were mostly men. 
The main function of the "support group" was to provide material and moral assistance to Gabyshev.

There were several conflicts in the group that erupted because of Raven. The squad members repeatedly reproached him for moral and financial dishonesty and called on Gabyshev to expel him. After Gabyshev's first arrest, which took place on September 19, Raven was even expelled from the "squad" by the remaining members. Nevertheless, Gabyshev used to defend Raven from attacks and take his side: "All of you are irreplaceable for me. And Raven is also unique to me. Yes, he is a terrible person - deceitful, black, traitor, cowardly, greedy, impudent, but if you can forgive him, we will overcome this darkness without fail" (Ibid.). The conflict around Raven arose several times. Such stubbornness on Gabyshev's part caused condemnation and bewilderment, misunderstanding by the group members, why exactly Raven is so important for "Sasha the Shaman".

On the one hand, apparently, Raven, like Angel, was important for the "shaman warrior" as part of his personality, personal identity: "I got to know Angel as an enlightened person. I learn more from him, he is my amulet, keeper, teacher. <...> My bright wing, he is the most enlightened person in the squad, our saint. From the sinner to the saint, they are all my powers" (Ibid.). Another time Gabyshev explained in a simple way what Raven meant to him: "I tell him: you are my black wing, I accept you as you are, and I will never expel you. How can I tear off my own wing and throw it away?" (Ibid.). Undoubtedly, both Raven and Angel had a special meaning, Gabyshev singled them out as a couple, as the antithesis of the dark and light beginnings of his soul. The plot of the story here again plays an important role, since these two were the first he met on his way, and both of them made a decision to go along with Gabyshev.

On the other hand, the reluctance to expel a person who has obviously tarnished his reputation with financial dishonesty again goes back to the pattern of behavior of the Orthodox holy fool. The solution, which seems to be out in the open, is rejected: "You are going to get him down. Even I can kill him with one blow. And you compete with him, shame on you. Show your strength to tough bandits" (How to Treat Raven 2019). Instead, it is proposed to forgive the guilty one, who continues over and over again to discredit Gabyshev and his supporters. Unwillingness, inability to forgive the guilty person turns against more honest supporters of Gabyshev, causing them to be denounced. Intercession, protection of the guilty person before the "crowd" is transformed into the exposure of honest, decent "righteous men", which is accompanied by an indication of their weakness.

\section{"Taking revenge is a sin, forgive"}

On the whole, the socio-political program of the "shaman warrior" can hardly be called such. Rather, it is a certain set of views, which can very conditionally be designated as a kind of "popular socialism". On the other hand, the "shaman warrior" never set himself the task of formulating any program. To the same extent, he is far from the current political agenda. His views are also characterized by abstract maximalism: "We need to save the Earth, save the white light, save the good, so we must be together. Forgive, learn to forgive inside yourself" (AFD 2019-2020: Gabyshev).

Again, like the Russian holy fools, Gabyshev was not interested in social changes or reforms: "The holy fool does not encroach on the state order, he denounces people, not circumstances" (Panchenko 1999: 394). The state system (its justice or injustice) worries Gabyshev only to a small extent: "I am not going to change the state system..." (AFD 20192020: Gabyshev). Criticism of injustice turns into grotesque utopianism: “...to nullify all debts to the population and start over $\langle\ldots\rangle$ As for the prison system... let it be the most humane in the world, grant amnesty to almost everyone" (Ibid.). Gabyshev is characterized by the intonation of a preacher, although he spoke publicly only once - at a local opposition rally in Chita in July 2019. In the autumn-winter of 2019-2020, he increasingly began to 
appear on YouTube, where he had the opportunity to "preach" to a fairly large number of viewers (the number of views ranged from several hundred to several thousand). It should be separately emphasized that since the summer of 2019, Gabyshev advocated maximum openness. In fact, on the road and in the camp, where he and his companions stayed overnight, anyone could make and upload videos. The same "transparent policy" continued in Yakutsk when Gabyshev stayed at home under investigation.

The topics covered by Gabyshev were very different: from organizational issues to "spiritual" ones dedicated to the struggle between light and darkness in the Universe. The most frequent and constant motive in these sermons was the issue of nonviolence: "These are the most basic principles of my faith, my credo... Taking revenge is a sin, forgive. Attacking is a sin, defend. To love your neighbor means to protect your neighbor. Forgiveness to everyone" (AFD 2019-2020: Gabyshev). Nonviolence in his worldview is of absolute value. This category is transferred by him to the "dark forces", which are also perceived as an object for preaching; "dark forces" are also capable of moral cleansing:

They fulfilled the very principle of my law: taking revenge is a sin, forgive. See what a paradox. $<\ldots>$ There are constant quarrels in the squad, the country somehow learns this. As I said, these are changes - and they quickly accepted it. They treat me as an aksakal, only "Aleksandr Prokopyevich", only "Uncle Sasha". You see who accepted my first teachings, they are law enforcement agencies - the police, the Federal Security Service. So they change, I am thankful to them for that (Ibid).

Here the model of behavior of the Russian holy fool is re-reproduced: he reproaches his "bright forces" for insufficient internal work, while the security forces who opposed him and brought him again to Yakutsk from the Trans-Baikal Territory are turning from dark into bright ones. Within the framework of the usual logic, Gabyshev should have censured and blamed, but he once again praises them in an illogical way and even puts them above his own supporters.

$* * *$

The case of Aleksandr Gabyshev can be called unique without exaggeration. His worldview and behavior model reflected the synthetic interweaving of two traditions, two cultures - Yakut and Russian ones. "Sasha the Shaman" consciously or unwittingly places himself in the framework of the Orthodox tradition, but, at the same time, uses the elements of (neo)shamanism, which is familiar to him in an ethnocultural way. On a superficial examination, Gabyshev seems to be a marginal person - a person who has dropped out of society or been rejected by it because of his behavior and mental state. Nevertheless, under the guise of an "urban madman," there is a kind of artist who interprets his own life as a work of art with a plot basis and empowers himself with the right to invent his own rituals and forms of self-expression. So far, the plot of the "campaign" to Moscow, conceived by the author, has undergone changes, but this does not mean that in the future Gabyshev's need for self-expression will not seek new forms. The invention of an original personal identity is to a large extent a creative act, in which he exists simultaneously both as a creator of his own personal story ("fairy tale") and as an actor, a character.

Gabyshev stands outside cultural standardization and sometimes opposes it, comes into conflict with it - as in the case of a dispute with Buryat shamans. This controversial position of Gabyshev has become the subject of criticism and attacks intended to challenge his status, the identity of a "shaman warrior" invented by him. In this case, holy foolishness becomes a powerful creative force, which is the foundation of the behavioral model and partly removes the claims made to him, since it is largely based on paradoxicality. The status of a "shaman", which is imaginary for one part of society and real - for others (supporters and sympathizers), simultaneously performs a protective function, since Gabyshev's mental 
sanity was questioned by those around him. Both serve as an important resource for him, allowing him to build a personal identity. Perhaps the idea of going on foot dates back to the pattern of behavior of the Russian holy fool, and following Procopius Ustyuzhsky, Gabyshev repeats by his act: "I want... to set off and go on a journey on foot" (quoted from: Ivanov 1994: 142).

\section{Sources and materials}

Aleksandrova 2020 - Aleksandrova, S. 2020. Yakutskii shaman: "Sud'ba prezidenta tol'ko v ego rukakh i v rukakh Boga" [Yakut Shaman: "The Fate of the President Is Only in His Hands and in the Hands of God"]. SakhaDay. July 28. https://sakhaday.ru/news/yakutskiy-shaman-sudbaprezidenta-tolko-v-ego-rukah-i-v-rukah-boga?from=timeline

Akhmirova 2020 - Akhmirova, R. 2020. "Eto karatel'naia psikhiatriia": advokat Gabysheva schel ego politzaklyuchennym [“This Is Penal Psychiatry": Gabyshev's Lawyer Considered Him a Political Prisoner]. Sobesednik. July 7. https://sobesednik.ru/politika/20200707-eto-karatelnayapsihiatriya-ad

Batalova 2020 - Batalova, Y. 2019. Mozhet povtorit' [Can Repeat]. Novaya Gazeta. October 14. https://novayagazeta.ru/articles/2019/10/14/82350-mozhet-povtorit

Golubev 2019 - Golubev, A. 2019. V gostyakh: Aleksei Tsydenkov, glava respubliki Buryatiia [Visitor: Aleksey Tsydenkov, Head of the Republic of Buryatia]. Echo of Moscow. Interview. September 22. https://echo.msk.ru/programs/beseda/2505993-echo

Egorov 2020 - Egorov, V. 2020. Dzhol. Letopis' pokhoda shamana-voina [Dzhol. Chronicle of the Campaign of the Shaman Warrior]. Samizdat Magazine. August 31. http://samlib.siwatcher.ru/e/ egorow_w_a/dyol.shtml

Ilyakhov $19 \overline{9} 4$ - Ilyakhov, P.N. 1994. Iz zhizni velikogo shaman [From the Life of a Great Shaman] (Translated from the Yakut language by S. Rufov). Yakutsk.

Interview 2019 - Interv'yu s yakutskim "shamanom" Aleksandrom Gabyshevym [Interview with the Yakut "shaman" Aleksandr Gabyshev]. YouTube. NewsYktRu: Promptly and Reliably. October 10, 2019. https://www.youtube.com/ watch?v=ApT2KoLRwV8

How One Yakut 2019 - Kak odin yakut vsiu Rossiyu perepoloshil [How one Yakut Alarmed the Whole of Russia]. YouTube. Editorial Office. November 14. https://www.youtube.com/watch?v=R hdrfOViH $8 \& \mathrm{t}=5 \mathrm{~s}$

How to relate to Raven 2019 - Kak otnosit'sia k Voronu? Pochemu perenesli zasedanie suda? [How to Relate to Raven? Why Was the Court Hearing Postponed?]. YouTube. Victor Egorov Santa Claus. October 16. https://www.youtube.com/watch? $\mathrm{v}=\mathrm{FMYskf}-\mathrm{NSyzY} \& \mathrm{t}=483 \mathrm{~s}$

Castaneda 1992 - Castaneda, C. 1992. Uchenie dona Khuana: put' znaniia indeitsev plemeni yaki [The Teachings of Don Juan: A Yaqui Way of Knowledge]. St. Petersburg: IMPAKS.

Kozhedubov 2019 - Kozhedubov, A. 2019. Yakutskogo shamana Gabysheva zaderzhali posle vozobnovleniia pokhoda na Kreml' [Yakut "Shaman" Gabyshev Was Detained after the Resumption of the Campaign to the Kremlin]. Moskovsky Komsomolets. December 10. https://www.mk.ru/ social/2019/12/10/yakutskogo-shamana-gabysheva-zaderzhali-posle-vozobnovleniya-pokhodana- kreml.html

Squad 2019 - Otryad yakutskogo shamana ob"yavil o samorospuske posle ugroz ot silovikov [The Squad of the Yakut Shaman Announced Its Self-Dissolution after Threats from the Security Forces]. Novaya Gazeta. September 25, 2019. https://novayagazeta.ru/news/2019/09/25/155592otryad-yakutskogo-shamana-ob-yavil-o-samorospuske-posle-ugroz-ot-silovikov

Peskov does not know 2019 - Peskov ne znaet, kto i kak zaderzhival yakutskogo shaman [Peskov does not know who detained the Yakut Shaman and How He Was Detained]. TASS. September 20, 2019. https://tass.ru/obschestvo/6909721

AFD - Author's Field Data. Expedition to the Trans-Baikal Territory, the Republic of Buryatia, the Republic of Sakha (Yakutia). July 2019 - February 2020.

Shaman 2019 - Shaman Yakut protiv Putina. O smerti zheny, svoem sumasshestvii i vole Boga [Yakut Shaman against Putin. On the Death of His Wife, His Madness and the Will of God]. YouTube. Decembrist. July 1, 2019. https://www.youtube.com/watch?v=ZYEfOPt26pg

Shamans 2019 - Shamany tengeri ustroili zaslon Shamanu Voinu [Tenger Shamans Set up a Barrier for the Shaman Warrior]. YouTube. Igor Kon. August 29, 2019. https://www.youtube.com/ watch?v=Rj7UQjGmyXw 
Shaman 2020 - Shaman - o pokhode. Priekhal Pavel "Loki" [Shaman about the Campaign. Pavel "Loki" Has Arrived]. YouTube. "Lekha the Cat". January 12, 2020. https://www.youtube.com/ watch? $=$ kmukdseqqJw

\section{References}

Ivanov, S.A. 1994. Vizantiiskoe yurodstvo [Byzantine Foolishness]. Moscow: Mezhdunarodnye otnosheniia.

Kharitonova, V.I. 2004. Shamany i shamanisty: nekotorye teoreticheskie aspekty izucheniia shamanizma i inykh traditsionnykh verovanii i praktik [Shamans and Shamanists: Some Theoretical Aspects of the Studies of Shamanism and Other Traditional Beliefs and Practices]. Etnograficheskoe obozrenie 2: 99-117.

Kharitonova, V.I. 2016. "A u nas vse shamany - pravoslavnye...": sovremennyi (neo)shamanizm i problema kul'turnoi identichnosti ["Our Shamans Are All Orthodox Christians...": Modern (Neo) shamanism and the Issue of Cultural Identity"]. Sibirskie istoricheskie issledovaniia 1: 105-133.

Kharitonova, V.I. 2020. Transformatsii shamanizma v sovremennoi Rossii, ili Kuda idem my s chudachkom? [Transformations of Shamanism in Contemporary Russia, or Where Are We Heading with the Freak?]. Sibirskie istoricheskie issledovaniia 2: 251-275. https://doi.org/10.17223/2312461X/28/15

Panchenko, A.M. 1999. Russkaia istoriia i kul'tura: raboty raznykh let [Russian History and Culture: Works from Different Years]. St. Petersburg: Yuna.

Yurkov, S.E. 2003. Pod znakom groteska: antipovedenie v russkoi kul'ture (XI-nachalo XXvv.). [Under the Sign of Grotesque: Antibehavior in Russian Culture (the $11^{\text {th }}-$ Eary $20^{\text {th }}$ Centuries). St. Petersburg: Letnii sad. 